\title{
A Study on the Cultivation of Chinese College Students' Socialist Core Values in the New Media
}

\section{Age}

\author{
Yun Shi \\ College of Electromechanical Engineering \\ Binzhou University \\ Binzhou, China 256603
}

\begin{abstract}
With the development of information technology and digital technology, the new media has become an important way for contemporary college students to obtain information and express their demands. This brings new opportunities and challenges to the ideological and political education of college students. In the face of the new situation, it must always carry out the concept of innovation and development, take the initiative to seize the new position of ideological and political education of the network, and actively cultivate the "young opinion leaders" of college students, and constantly improve the timeliness of college students' education on socialist core values. And then, it can achieve the education of the socialist core values of the current college students.
\end{abstract}

Keywords-new media; the concept of innovative development; the socialist core values

\section{INTRODUCTION}

The "Opinions on Cultivating and Practicing the Socialist Core Values" issued by the General Office of the CPC Central Committee in December 2013 emphasizes that "the process of cultivating and practicing the socialist core values into the of national education" [3]. Colleges and universities as an important part of China's education, should take the mission actively, and then consciously become the important positions of cultivation and implementation of the socialist core values. Xi Jinping, the general secretary put forwards the five development concept of the discussion, such as "innovation, coordination, green, open and shared". It provides a new perspective for our education. In order to accelerate the reform and development of colleges and universities, it should firmly establish and implement the five development concepts, which are also the concrete manifestation of the socialist core values in the development [2]. Especially in the new media era, with the new situation in the field of education, it should integrate the idea of innovation and development into the socialist core values of college students' education. And it has important and far-reaching practical significance.

Project Title: The Research Fund Project of Binzhou University, the Youth Project, and "A Study on the Role of Occupational Identity in construction of Specialized University Counselors" Project Number: Bzxyrw1211

\section{II. "NEW MEDIA" AND COLLEGE STUDENTS IDEOLOGICAL AND POLITICAL EDUCATION}

Compared to the traditional media, "New media" is accompanied with the development of new technologies. There are many differences in the communication channels, audience, and information content and traditional between new media and traditional media. The unified concept in academia can be summarized as the following: New media is a kind of media based on digital technology, network as the carrier. It can achieve the spread of all to all and play the functions of the media. From the above concepts, it can be seen that the differences between new media and traditional media are whether the development and application of new technologies can produce profound changes in mass communication. Paper media is the first media. The broadcast media is the second media. And television media is the third media. The Internet media is the fourth media. And the mobile phone side media is the fifth media. The media enters into people's lives with the development of technology and times. From this trend, it can conclude that the new media in this age will become the traditional media in the future one day. So, no matter what definition it gives to the new media, the functions of the new media will be accompanied with the development of science and technology. The support of digital and interactive technology for the new media would provide users with a more open and interactive information space. Therefore, the concepts of innovation and development are in line with the requirements of the new media in this age.

In a large number of people on-line, college students are the main body. Their network applications are very active, and their abilities to learn and receiving abilities are strong. It is easy to accept new ideas and methods. And they are the "beach-goers" in the new media age. Under this situation, colleges and universities face the new opportunities in cultivating the socialist core values. And it is also a new challenge. This "double-edged sword" that making good use of the new media also puts forward higher requirements for counselors' work. The Ministry of Education, Higher Vocational Counselors' Professional Competence Standards (Temporary), puts forward different requirements for the different levels of counselors on the network ideological and 
political education in the counselor professional function part. It requires us not only to grasp the students' application of information technology, but also to be familiar with the characteristics and rules of the network language. It should use various types of new media technology in expertly, and ultimately carry out the depth study with their own work experience on the network of ideological and political education. It is not only the improvement of work standards, but also the sublimation of the theory of work from the work to the practice [5]. Therefore, in the new media age, counselors must follow the trend of the times. And then, they should change the ways and channels of work. And the new media as a new carrier of ideological and political education, the counselors should build a new platform for multi-dimensional publicity and education. And then, the counselors are close to reality, close to life, close to the students in the cultivation of the core socialist values.

\section{INNOVATION AND DEVELOPMENT ARE THE} INEVITABLE REQUIREMENTS IN THE EDUCATION OF THE SOCIALIST CORE VALUES

Since the 18th National Congress of the Communist Party of China, the general secretary, Xi Jinping has attached great importance to innovation. And he also demanded that "innovation must be the first force to lead the development, the talents as the first resources support the development, the innovation is the core in the national development [6]". In the five concepts of development, "innovation" is put in the primary position, which includes theoretical innovation, institutional innovation, technological innovation, cultural innovation and other aspects of innovation. And it is throughout all the work of the party and the country. And it also points out the directions and requirements for the national development of the country [7]. In the final analysis, human innovation is derived from the innovation of education. The educator, Zhu Yongxin believes that the dissemination, transformation and application of knowledge are the basis of innovation. Any innovation can not be separated from education, and innovation should be deeply rooted in the basis of education. The experiences of other advanced countries also tell us that innovation is an inexhaustible motive force for the prosperity of a country. And education as a basis for innovation, it must continue innovating. If it does like that, with the trend of the times, it can cultivate the high-quality talents with innovative consciousness and innovative ability [8].

New media with its high degree of openness and convenience is very popular among the college students. It meets the students' various needs in the study and life. At the same time, its development and application have tremendous influences on the college students in the cultivation and practice of the socialist core values. At present, China's mainstream media is actively facing the transformation of new media. And in this process, it produces a large number of high-quality new media content. Based on the rapid development of the internet and intelligent terminals, students use micro-blogging, WeChat and other "micro" tools to voice, to follow and to accept new information. Everyone can be said to be a communication node on the Internet. And everyone have the opportunity to express themselves. Mobile intelligent terminals have been closely related with the college students. The college students receive information and express themselves with the mobile phones and other tools. Similarly, the ideological and political education must be keep up with this situation. And it also should take the initiative to adapt to this feature, fit the reality life of college students. And then, it should try to assimilate into the college students with the depth into the network. Based on this situation, it can seize the opportunity to promote the socialist core values. And it can use the new media in an innovative way. The advantages of new media will have influences on the education. Advancing with the times, it should cultivate the socialist core values with new ideas, new ways, and new practices.

IV. The Countermeasures of DeVEloping College STUDENTS' SOCIALIST CORE VALUES WITH THE CONCEPT OF INNOVATION AND DEVELOPMENT

\section{A. To Give Publicity to Education with Innovation, Leading the Discourse Right of College Students' Ideological and Political Education}

The general secretary, Xi Jinping stressed that it should use various opportunities and occasions to form the living scene and social atmosphere to nurturing and carrying forward the socialist core values. And then, the impacts of the core values are like air everywhere, anytime [9]. For the counselors, the innovative propagandist ways of the education of the socialist core values and the effective use and guidance of new media are both the necessary requirements for the development of counselors' professional competence, and have become a new channel for counselors to get through and use the information exchange with college students. It requires the counselors to be careful, detailed and practical in the publicity and education on the socialist core values. It should innovate the working methods, make full use of the advantages of new media. And with this trend, they can take the socialist core values to the students. Then, the informations of the socialist core values in school are more abundant.

In order to lead the discourse right of college students' ideological and political education, the counselors need to deeply grasp and understand the characteristics and rules of the new media era, and strive to make the mainstream ideology more influential. First of all, counselors should have a deep understanding of new media; make good use of the new media tools. The counselors should be familiar with the ways of thinking and learning habits of college students through various ways. And they should grasp the students' ideological trends in time, and guide students to establish the correct outlook on life, values and world view. Secondly, the counselors need to make the innovation of the content of new media. The counselors should take the initiative to use the network language which is more close to the students' reality to communicate with the students. So that, the subjective demands of students can be more smoothly reflected. Thirdly, the counselors should always pay attention to network public opinions to analyze the students' 
dynamic with their keen thinking. The counselors must understand all the information quickly, master the core information, and analyze the reasons why these things spread in large scale. And they also should grasp the directions of the development of public opinion and use the new media to seize the right to speak. It can effectively guide students to correctly view the network public opinion. And it can also be the effective solution to eliminate the negative impacts of network public opinion.

\section{B. To Advocate the Innovation in Demonstration and Leadership, Cultivating "Young Opinion Leaders" of College Students}

About the "Opinions on Further Strengthening the Management of Campus Network in Colleges and Universities", the Ministry of Education and the Communist Youth League Central Committee put forward some specific requirements that on the formation of a special team of teachers, the types of teams, the ways to carry out the network education and other specific requirements. It requires selecting a group of teachers with rich knowledge and political faith as network commentators. And these commentators are familiar with the characteristics and rules of the network language. They can write articles on the hot questions and attract students to click and comment. And thus, they would take the initiative to guide the discourse right of the network speech [10]. So, the college counselors should take the initiative to be an on-line commentator, and actively enrich their knowledge and enhance the recognition of the new media. According to learning to master the ways of using the new media, the college counselors should enhance their information literacy, especially the ability to resolve the interference in the face of network public opinion with the Internet language timely. On the other hand, the college counselors should guide students to cultivate and practice the socialist core values. And what's more, they should select the "young opinion leaders" from the students to cultivate. And then, these network activists in the new media age can analyze, demonstrate, lead and organize the network public opinions and major events.

The "young opinion leaders" are from the college students. In turn, they should serve the college students. Such as the forum moderators of college students, lord of a bar, the persons who have hit the micro-blogging and have transmit WeChat for many times, they are usually active on the web. And they regularly update or transmit the web contents that are attractive to students every day. They also express their own opinions and disseminate them to the majority of students in an explicit or implicit manners. People in the university stage, the plasticity of thinking are still relatively strong. And the outlook on life and world view can also be shaped in a new direction. The educators can guide them to focus on positive information with using their desire to the new knowledge and new things. However, the college students in the psychology and emotion are blind, impulsive. Their mental and rational ideas are still in the immature stage. And in this case, they are easily influenced by the legend people of the new media, and they would easily make irrational judgments without understanding the relevant facts. Therefore, to cultivate the "young opinion leaders" around us and to play the demonstration and the leadership of the "youth opinion leaders" have great significance for the cultivation of the socialist core values.

In the new media age, the western ideology invades the ideology of our nation in a more convenient way, especially the youth groups. They try to change the mainstream ideology of our country and dilute our excellent traditional culture and obliterate our ideological and political education. Recently, the president of the University of Hong Kong expressed opposition to "sovereign independence of Hong Kong" at the opening ceremony in the public. However, the president of the student union of the Hong Kong University expressed his approval openly. It became a hot topic of public opinion. As a president of the student union of the University of Hong Kong, he can advocate "sovereign independence of Hongkong" at the opening ceremony. In a certain extent, it reflects the political inclination of the student union of the Hong Kong University. It sounded the alarm in the ideological and political education. It urges to cultivate the "young opinion leaders" in the network world who are in line with our socialist core values. And they can issue our own mainstream ideology. The student cadres and the student party members who support the leadership of the Communist Party of China, and who have the positive ideology, mature and rational ideas should become the training objects and the majority of reserve forces. And they should be the "youth opinion leaders". Through their creation of the new media that reflects the characteristics of the times, it resolves the extreme erroneous remarks and spread the positive energy in the campus. And it also creates a healthy campus culture atmosphere.It is good for cultivating and practicing the socialist core values.

\section{CONCLUSION}

To sum up, if it wants to cultivate the socialist core values of college students, it must use the concept of innovation and development in the new media era. It should integrate the socialist core values into the regular works of ideological and political education in colleges and universities. And it should strengthen the use of new media, build a new platform for multi-dimensional publicity and education, actively cultivate the young opinion leaders of college students, and guide the discourse of university students' ideological and political education. Colleges and universities will be established as important places for cultivating and practicing the socialist core values. In this way, the cultivation of socialist core values is really close to the reality, the life and students.

\section{REFERENCES}

[1] Zhang Daliang. To lead the reform and development of colleges and universities with five concepts of new development ideas [J]. China Higher Education, 2016, (5): 1-1

[2] Chai Wei. To understand the theoretical and practical significance of the five development concepts in depth [EB/OL]. 2015, 12, 8. http://www.jyb.cn/china/gnxw/201512/t20151208_645965.html

[3] Opinions on nurturing and practicing the socialist core values [EB/OL]. 2013, 12, 23. http://news.xinhuanet.com/politics/201312/23/c_118674689.htm 
[4] Ji Haiju. Research on Ideological and Political Education in Colleges and Universities in the New Media Age [D]. Nanjing Normal University, 2013,26-27

[5] The professional standards of higher vocational counselors (provisional) [EB/OL]. 2014, 4,14. http://www.gov.cn/xinwen/201404/14/content_2658616.htm

[6] In May 4, 2004, An important speech with the representatives of outstanding youth representatives by Xi Jinping [EB/OL]. (2014-1009). http://news.cyol.com/content/2014-10/09/content_10760589.htm

[7] $\mathrm{Xi}$ Jinping's speech on innovation [EB/OL]. 2016, 3, 1. http://politics.people.com.cn/n1/2016/0301/c1001-28159755.html

[8] Zhu Yongxin. To Lead the "13th Five-Year Plan" Education Reform and Development with the five concepts [EB/OL]. (2015-11-16). http://www.qstheory.cn/zhuanqu/bkjx/2015-11/16/c_1117153993.htm

[9] Xi Jinping's speech at the thirteenth collective study of the Political Bureau of the CPC Central Committee [EB/OL]. (2014-02-25). http://www.gov.cn/ldhd/2014-02/25/content_2621669.htm

[10] Opinions on Further Strengthening the Management of Campus Network in Colleges and Universities of the Central Committee and the Communist Youth League of the Ministry of Education (Teaching Society, 2004, No. 17) [EB/OL]. (2015-01-15).

[11] http://www.qggzszk.org/index.php/Home/Article/shows/id/1059

[12] The Vice Chancellor opposite the sovereign independence of Hongkong at the opening ceremony, the president of the student union actually provoked [EB/OL]. (2016-08-27). http://news.sohu.com/20160827/n466323384.shtml 